\title{
PSEUDOTHECIAL MATURATION AND ASCOSPORE RELEASE OF Leptosphaeria maculans AND L. biglobosa IN SOUTH-EAST POLAND
}

\author{
Adam Dawidziuk ${ }^{1}$, Idalia Kasprzyk ${ }^{2}$, Joanna Kaczmarek ${ }^{1}$, \\ Małgorzata Jędryczka ${ }^{1}$
}

\author{
${ }^{1}$ Institute of Plant Genetics, Polish Academy of Sciences, Poznań, Poland \\ ${ }^{2}$ Department of Environmental Biology, University of Rzeszów, Rzeszów, Poland \\ e-mail: adaw@igr.poznan.pl
}

Received: 23.11.2009

\section{Abstract}

Stem canker of brassicas is a severe disease of oilseed rape in Australia, Canada and Europe, including Poland. The disease is caused by Leptosphaeria maculans and L. biglobosa - two pathogens belonging to the class Dothideomycetes. The species differ in pathogenicity, but they have identical shape and size of fruiting bodies and spores of the generative and vegetative stages. Both pathogens are often found together in infected tissues of oilseed rape plants.

The main goal of the experiments was to measure the rate of pseudothecial maturation and to monitor ascospore concentration of L. maculans and L. biglobosa in air samples. The paper is the first investigation on the generative stage development of these two species in south-east Poland. The studies were done for three consecutive years (2005-2007), for six most important months in pathogen development and plant infection, including 3 months in the spring (March - May) and 3 months in the autumn (September - November). The stage of pseudothecial maturation was assessed visually, based on the development of asci and ascospores. Monitoring of spore concentration in the air was performed using a Hirst-type 7-day volumetric trap.

It was proved that differences in pseudothecial maturation rate in south-east Poland, encompassing the climatic regions of the Carpathian Foothills and Cracow, do not exceed two weeks within one season. The first and the highest ascospore concentration dates depended on weather conditions in a particular season. The total number of spores during the studied seasons varied from 9 to 12 spores $/ \mathrm{m}^{3}$, which was from 70 to 90 times lower than the average from five other monitoring sites around Poland. The short exposition to spore showers and very small concentrations of $L$. maculans and L. biglobosa ascospores in air samples were the most probable reasons for relatively small damage of oilseed rape crops by stem canker in the south-east part of Poland.

Key words: ascospore, stem canker, Brassica napus, Leptosphaeria maculans, Leptosphaeria biglobosa, oilseed rape, pseudothecium, aeromycology

\section{INTRODUCTION}

Stem canker, also called blackleg, is a damaging disease of oilseed rape worldwide (F i t t et al. 2006). Serious crop losses are reported in Australia, Canada and Europe (Gugel and Petrie, 1992; Salisbury et al. 1995; Thürwächter et al. 1999), including Poland ( $\mathrm{J}$ ędry czka, 2007). The disease is caused by two pathogens from the class Dothideomycetes, the genus Leptosphaeria: L. maculans (Desm.) Ces et de Not. and L. biglobosa sp. nov. (S ho e make r and $\mathrm{B} \mathrm{ru} \mathrm{n,2001).} \mathrm{The} \mathrm{former} \mathrm{species} \mathrm{is} \mathrm{regarded} \mathrm{as} \mathrm{more}$ damaging and it is predominant in some countries, like Australia (Khangura and Barbetti, 2001). In contrast, L. biglobosa has been a predominant pathogen causing stem canker of oilseed rape in Poland ( $\mathrm{J} \mathrm{e}$ d r y c z k a et al. 1994). In recent years, the population has been gradually changing in favour of $L$. maculans (K a rolewski et al. 2002; J ę dryczka, 2007). Detailed data about L. maculans and L. biglobosa life cycles in different climatic regions allow to improve stem canker management through optimization of fungicide treatments.

The fungus is an ascomycete and produces generative fruiting bodies (pseudothecia) which contain ascospores. The ascospores of $L$. maculans and L. biglobosa are similar to identical, but their shape and size differs from the other representatives of Leptosphaeria spp., eg. L. nodorum, a serious pathogen of wheat. The ascospores of the studied species form primary inoculum infecting young plants of numerous Brassica crops, including oilseed rape (B. napus) - presently the most expanding crop in Poland (B a r t k o w i a k - B r o d a et al. 2005; GUS 2009). The formation of pseudothecia takes place on infected stubble from a previous season's crop (P e tri e, 1995). In our hemisphere, ascospores are mainly produced and dispersed in the autumn ( $\mathrm{Huang}$ et al. 2005; 
$\mathrm{Kac} z \mathrm{marek}$ et al. 2006). The rate of pseudothecial maturation and subsequent ascospore release depend on weather conditions, principally wetness (rain or dew) and temperature ( $\mathrm{S} \mathrm{a} \mathrm{la} \mathrm{m} \mathrm{et} \mathrm{al.} \mathrm{2003;} \mathrm{To-}$ scano-Underwood et al. 2003; Huang et al. 2007). The concentration of spores in the atmosphere depends on their sensitivity to weather changes (Hjelmroos, 1993; Stępalska and Wołek, 2005). Conducive weather conditions in summer and autumn lead to ascospore release and development of disease symptoms. In susceptible plants, the infections cause leaf spots. They usually contain asexual fruiting bodies (pycnidia) which release conidia (pycnidiospores). The fungus spreads from a leaf via a petiole to a stem (H a m m ond et al. 1985). The intensity of symptoms and severity of the disease depend on the date of infection and fungal growth rate in tissues of the host-plant as well as subsequent air temperature (Huang et al. 2003).

The aim of this work was to study the life cycle of L. maculans and L. biglobosa in the south-east region of Poland. The analyses included pseudothecial maturation and ascospore release of this species complex in the Carpathian Foothills and Cracow region. The investigation was done in order to search for an explanation of relatively low success of these pathogens in colonizing oilseed rape as compared to the west of Poland.

\section{MATERIALS AND METHODS}

\section{The location of the experiment and short char- acterisation of the climatic regions studied}

The experiment was located in the following two sites: 1) Krasne near Rzeszów (N5003'06", E22 $\left.05^{\prime} 20^{\prime \prime}\right)$; 2) Śledziejowice near Cracow (N50'00'10", E20 11'86"). In the spring samples were collected only from Krasne. The monitoring sites were located $150 \mathrm{~km}$ apart and they were both situated in regions with relatively infrequent cultivation of oilseed rape in comparison to the west of Poland. Rzeszów is located $40 \mathrm{~km}$ and Cracow is $50 \mathrm{~km}$ north of the Carpathian Mountains. Rzeszów province has an agricultural character; the environs are a mosaic of forests and crop fields. Agricultural land occupies a large area in the land use structure. The suburban region of Cracow is densely populated and mostly deprived of intensively used agricultural land. Both cities are located in the Upper Vistula Basin, which is a warm and temperate dry region. The vegetative period lasts 220-230 days. In Rzeszów annual mean temperature is $8.6^{\circ} \mathrm{C}$ and average precipitation is 712 $\mathrm{mm}$. The mean yearly temperature in Cracow is $0.4^{\circ} \mathrm{C}$ lower and rainfall varies from 700 to $750 \mathrm{~mm}$.

Evaluation of pseudothecial maturation of L. maculans and L. biglobosa
Experiments were done for three consecutive years (2005-2007). The autumn observations were done from 1 September to 30 November in 2005-2007 and the spring evaluation was done in the period between 1 March and 31 May in years 2006-2007. The development of L. maculans and L. biglobosa was monitored at weekly intervals. Maturation of pseudothecia was assessed based on fruiting body structure as well as the presence and the development stage of ascospores. Each year fragments of oilseed rape stubble with stem canker symptoms were randomly chosen (6 fragments per site $\mathrm{x}$ week). Fruiting bodies were isolated (10 per sample), squashed in sterile distilled water and observed visually by a light microscope (Zeiss Axiostar, Germany) using a 100 times magnification.

Fruiting bodies were divided into pycnidia (anamorph stage, producing pycnidiospores) and pseudothecia (teleomorph, producing ascospores). Pseudothecia were divided into five classes of maturation, based on the classification described by Toscano-Underwood et al. (2003):

- class A - immature pseudothecia;

- class B - pseudothecia with asci structures being formed;

- class $\mathrm{C}$ - pseudothecia with asci containing immature ascospores (less than 6 cells) and/or less than 8 ascospores in one ascus;

- class D - pseudothecia with asci containing 8 fully mature ascospores;

- class E - pseudothecia mature, but empty after the discharge of ascospores.

In total, 60 fruiting bodies were observed every week at each sampling site. The conclusions concerning the development process of L. maculans and L. biglobosa were based on the assessment of 7800 fruiting bodies.

Evaluation of ascospore concentration of L. maculans and L. biglobosa in air samples

The investigation of L. maculans and L. biglobosa ascospore concentration in air samples was done using a 7-day volumetric pollen and particle sampler (Lanzoni VPPS 2000, Bologna, Italy) located in Krasne at the ground level $(1 \mathrm{~m})$. The spore trap was surrounded by infected oilseed rape stubble which had been collected at the end of the previous season and kept outdoors to allow fungus development in natural weather conditions. The spore sampler contained a built-in vacuum pump, designed to sample airborne particles, including fungal spores. The air was actively sampled at a volume of 10 litres per minute. The air suction was checked at the beginning and middle of each sampling period. Particles were impacted on adhesive coated transparent Melinex tape supported on a clockworkdriven drum. After each week, the tapes were cut transversely in seven equal parts representing seven days (24-hour periods) of each week and then longitudinally 
in two halves. One half of the tape for each sampling date was stained with fuchsine, mounted with glycerol jelly to prepare a permanent microscope slide and then analysed under a light microscope using a 600x magnification. The second part of each tape was used for molecular analyses (results not presented in this study). The number of spores per slide was re-calculated to determine the ascospore concentration in $1 \mathrm{~m}^{3}$ of the air ( L a c e y and W e st, 2006). The results were expressed as the average daily number of ascospore in $1 \mathrm{~m}^{3}$ of the air. The sampling was done every year in the same periods as the pseudothecial development studies, i.e. for 3 autumn and 3 spring months.

\section{Weather data in the study period}

The influence of rainfall and temperature was studied based on weather data obtained from the meteorological stations located in Rzeszów-Jasionka (N50'06'35', E22 $\left.01^{\prime} 08^{\prime \prime}\right)$ and Cracow (N50'03'41', E19'56'18'") (Tab. 1). The distance between the weather monitoring stations and the experiment sites was $7 \mathrm{~km}$ for Krasne (Krasne-Rzeszów) and $10 \mathrm{~km}$ for Cracow (Śledziejowice - Cracow).

\section{RESULTS}

\section{L. biglobosa}

Pseudothecial maturation of L. maculans and

During the three experimental years, mature pseudothecia of L. maculans and L. biglobosa were always detected but there were considerable differences between the rate of their development in particular seasons.
In the autumn of 2005 in Krasne pseudothecia matured very quickly; no class D (fully mature) pseudothecia were found in the second week of the study (beginning of September), whereas one week later (mid-September) there was $51.7 \%$ of class D pseudothecia (Fig. 1). Their number increased to $78.1 \%$ in the first half of October. In the same season, monitoring performed in Śledziejowice allowed to detect mature pseudothecia 2 weeks later (second half of September) and their ratio was less than 7\% of all fruiting bodies (Fig. 2). The highest number of mature fruiting bodies (94.9\%) was observed in mid-November. In the 2006 season in Krasne, class D pseudothecia were observed at the end of September 2006 but this time with a very low rate of $1.9 \%$ (Fig. 1). In 2007 mature pseudothecia were found in the beginning of September with the rate similar to autumn $2005(54.5 \%)$. The highest percentages of mature pseudothecia were observed in November. In 2006 in Śledziejowice a small ratio $(4 \%)$ of mature pseudothecia was observed at the end of September 2006 (Fig. 1). In 2007 the pseudothecia maturation process at this sampling site was much faster; the first pseudothecia of class D were observed in the beginning of September and their percent was high (51\%). In mid-November 2006 matured pseudothecia constituted $94 \%$ of all fruiting bodies found on oilseed rape stubble. In 2007 the highest number of mature pseudothecia was observed much earlier - in mid-October; there was $94 \%$ of class D pseudothecia.

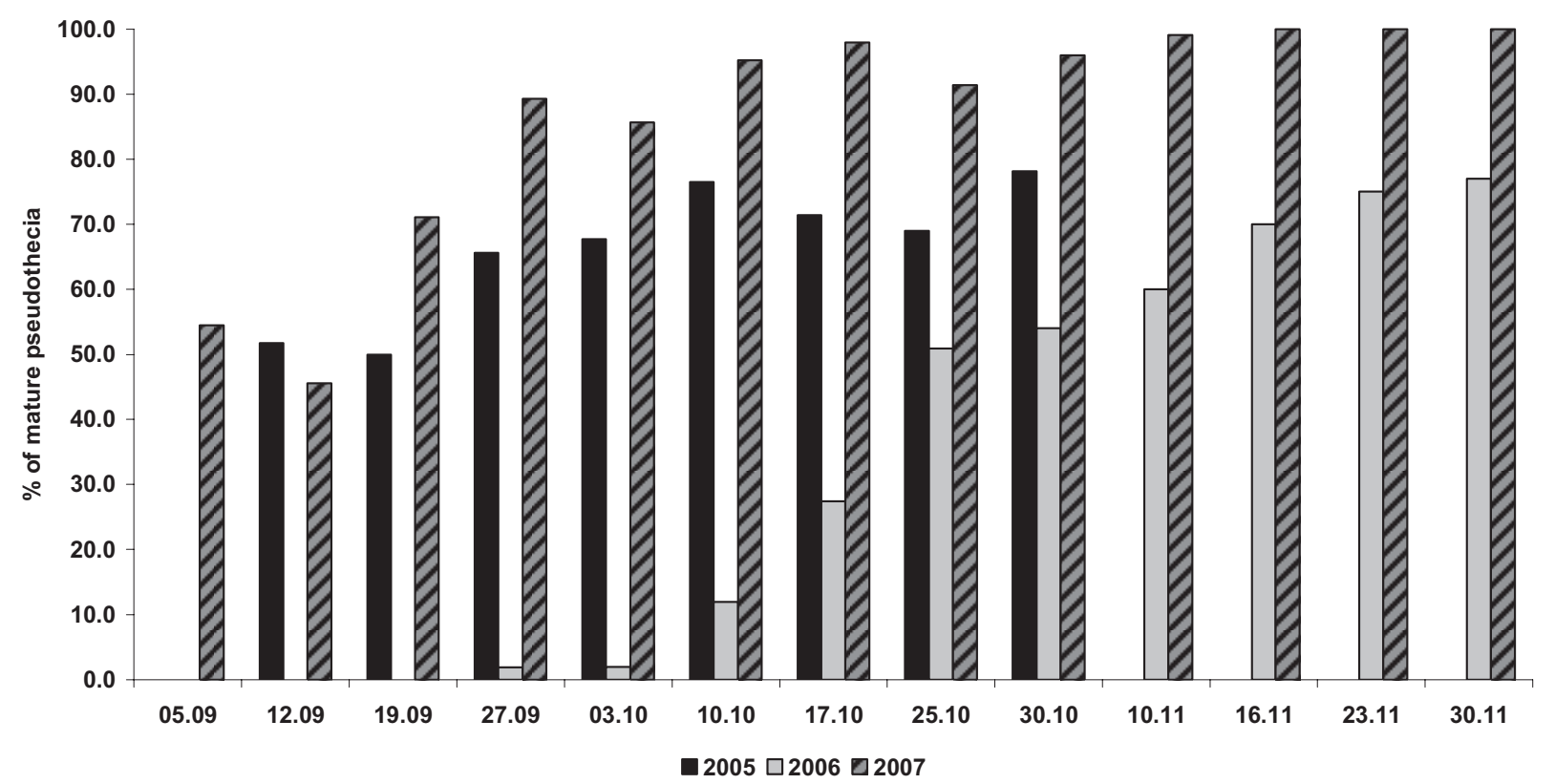

* no pseudothecial maturation data available for November 2005

Fig. 1. The percent of mature pseudothecia (class D) of Leptosphaeria maculans and L. biglobosa in total pool of fruiting bodies in the autumn of 2005-2007 in Krasne near Rzeszów (Carpathian Foothills) 


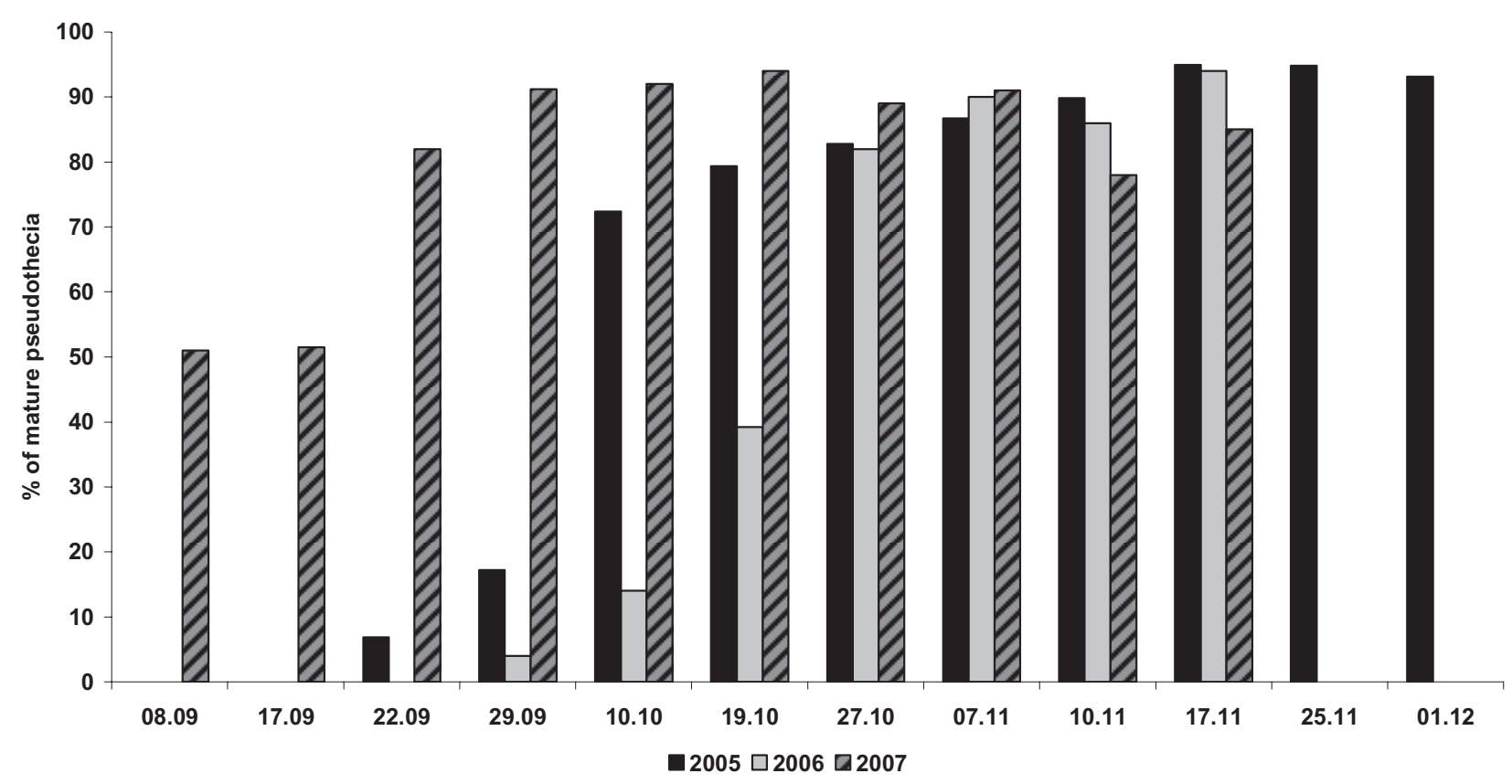

Fig. 2. The percent of mature pseudothecia (class D) of Leptosphaeria maculans and L. biglobosa in total pool of fruiting bodies in the autumn of 2005-2007 in Śledziejowice (Cracow region)

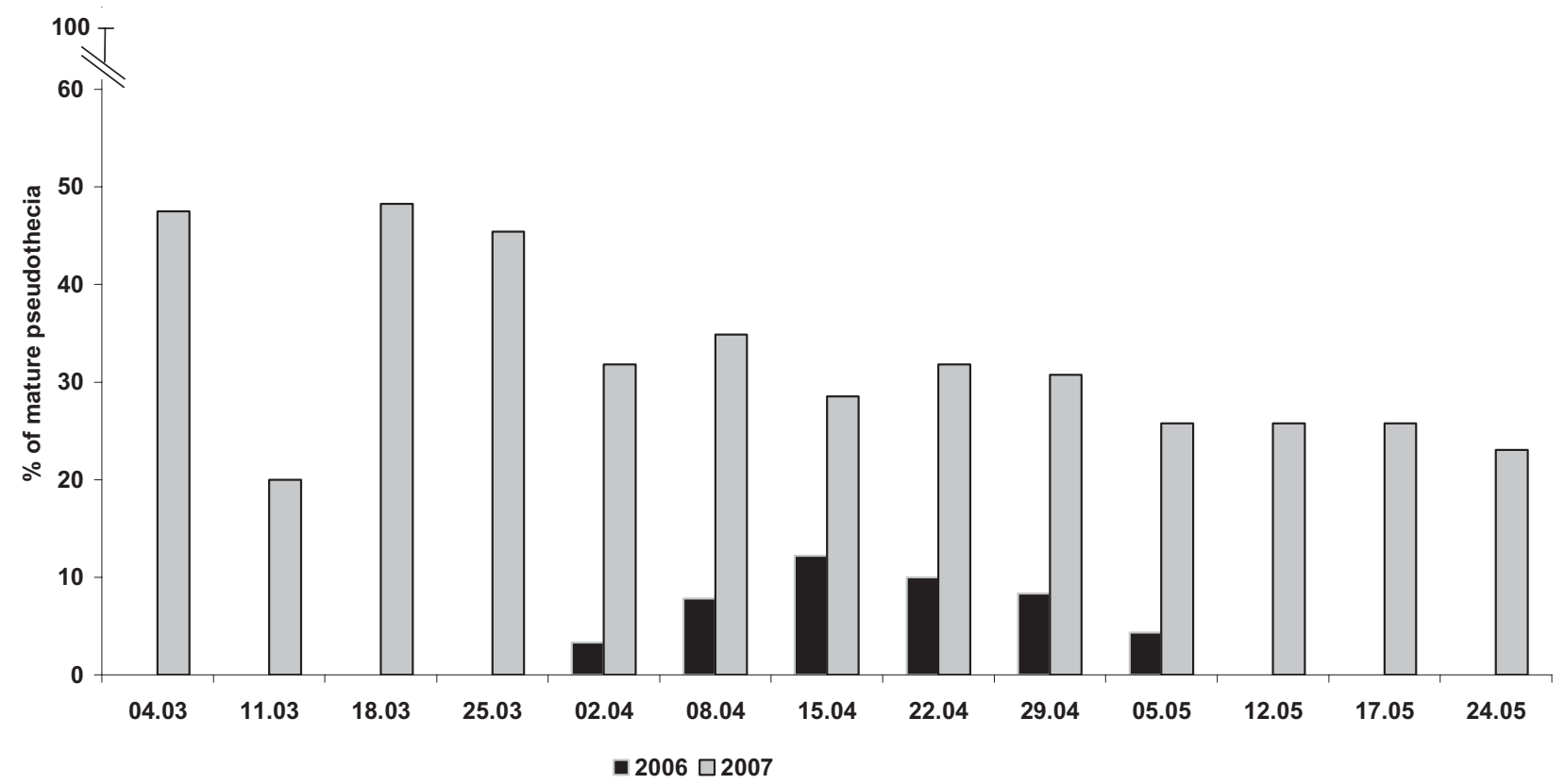

Fig. 3. The percent of mature pseudothecia (class D) of Leptosphaeria maculans and L. biglobosa in total pool of fruiting bodies in the spring of 2006 and 2007 in Krasne near Rzeszów (Carpathian Foothills) 


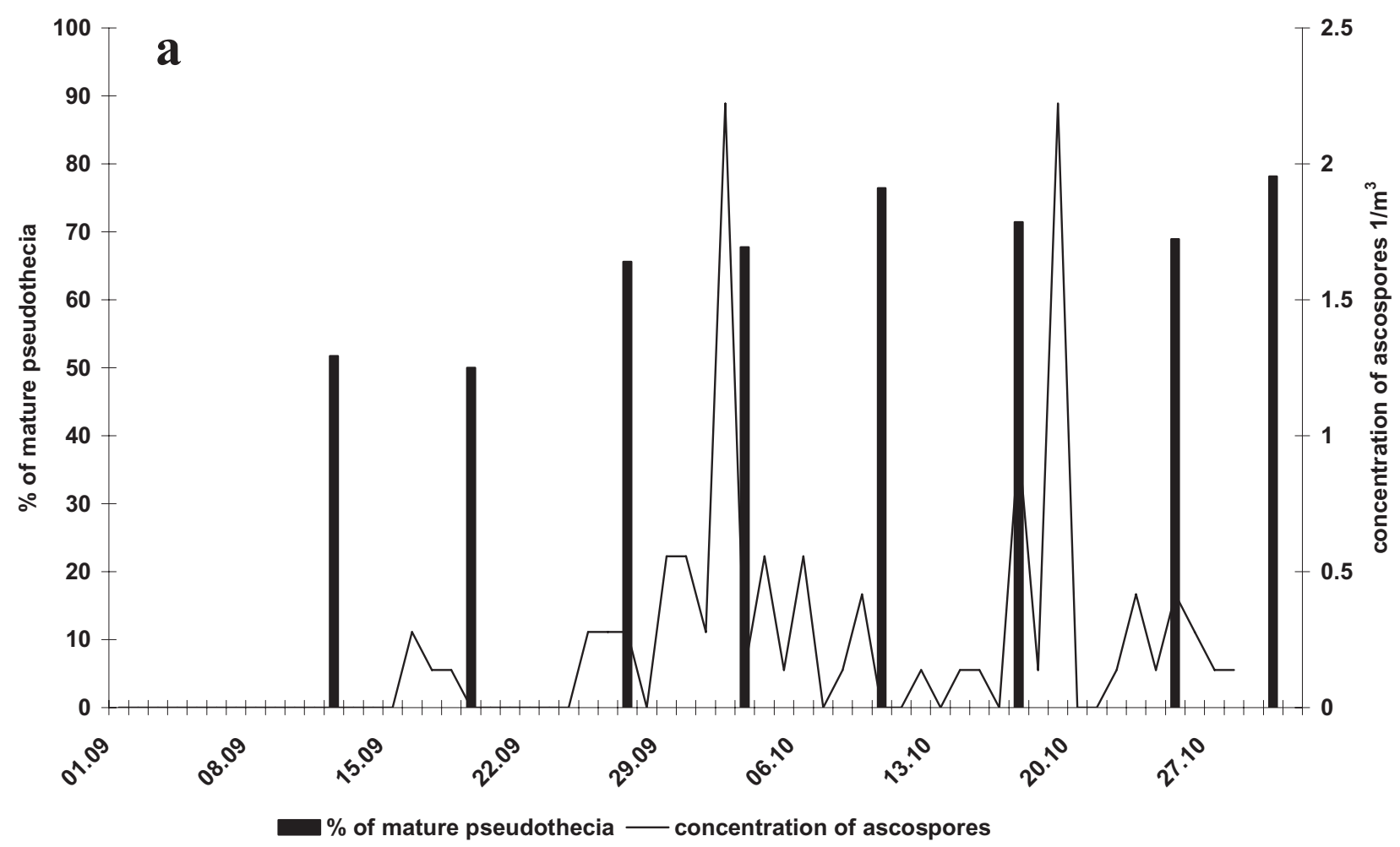

Fig. 4a.

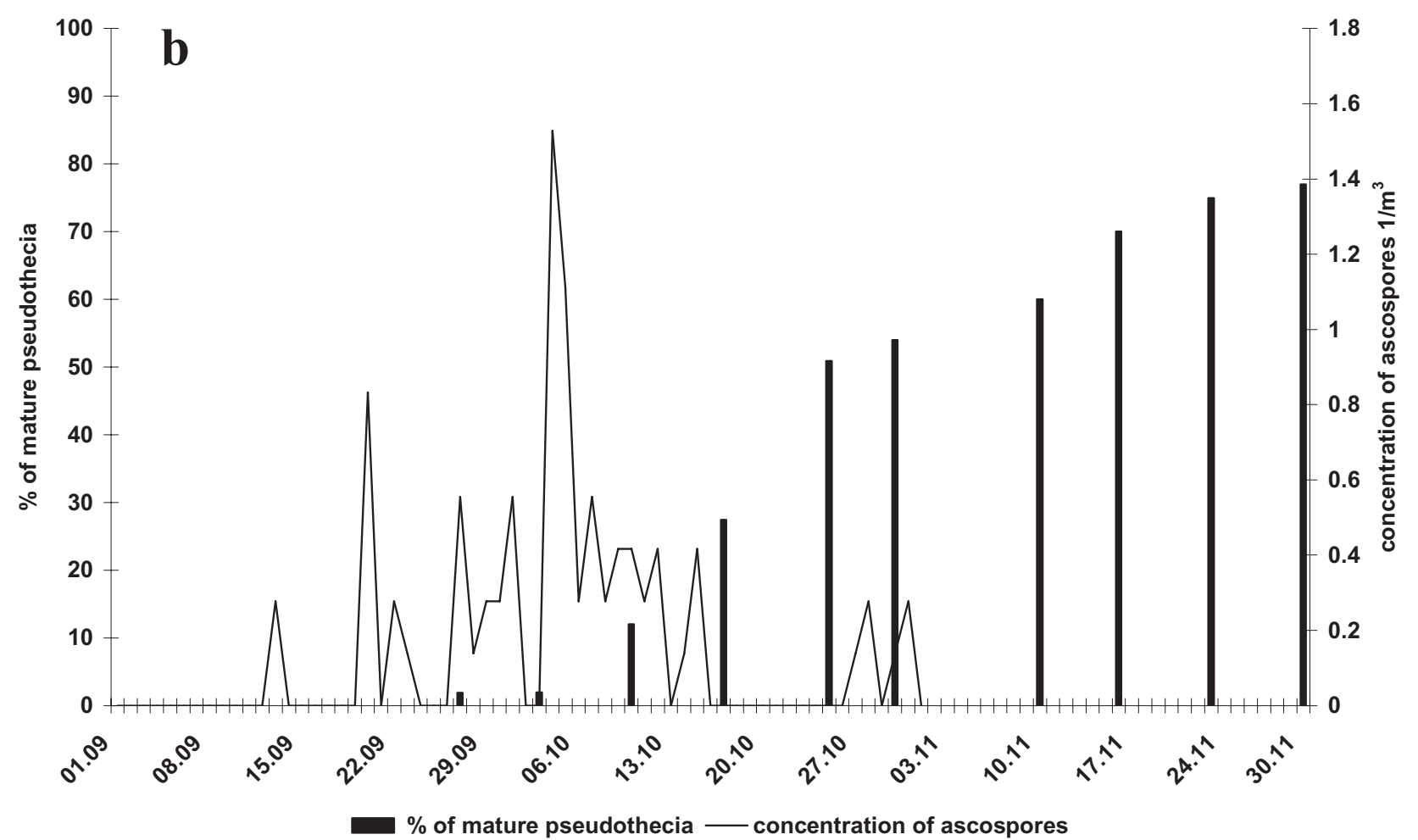

Fig. 4b. 


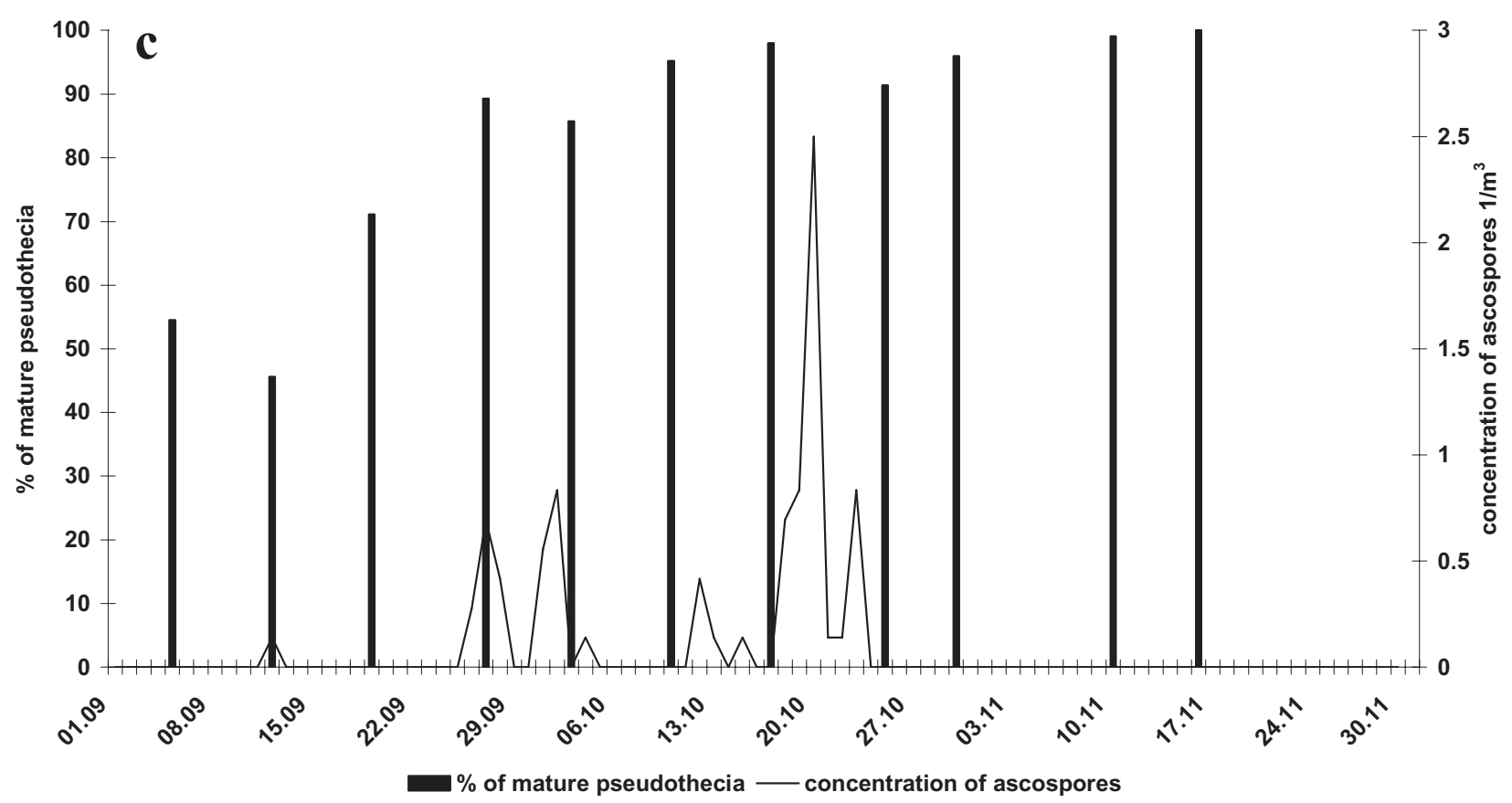

Fig. 4c. The concentration of ascospores in air samples (line) and the percent of mature pseudothecia (bars) of Leptosphaeria maculans and L. biglobosa in Krasne near Rzeszów, Carpathian Foothills, in the autumn of: a) 2005, b) 2006 , c) 2007.

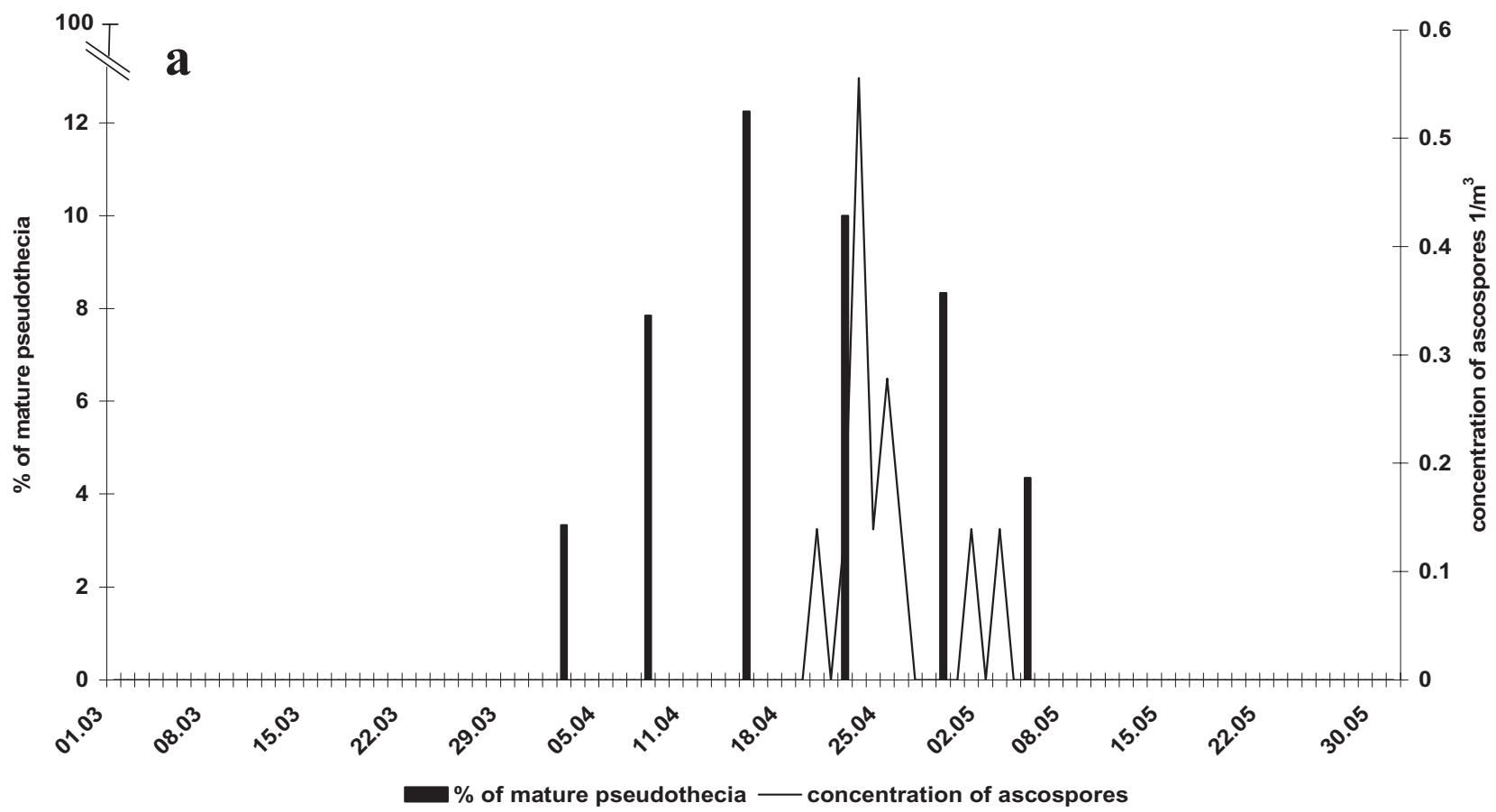

Fig. 5a. 


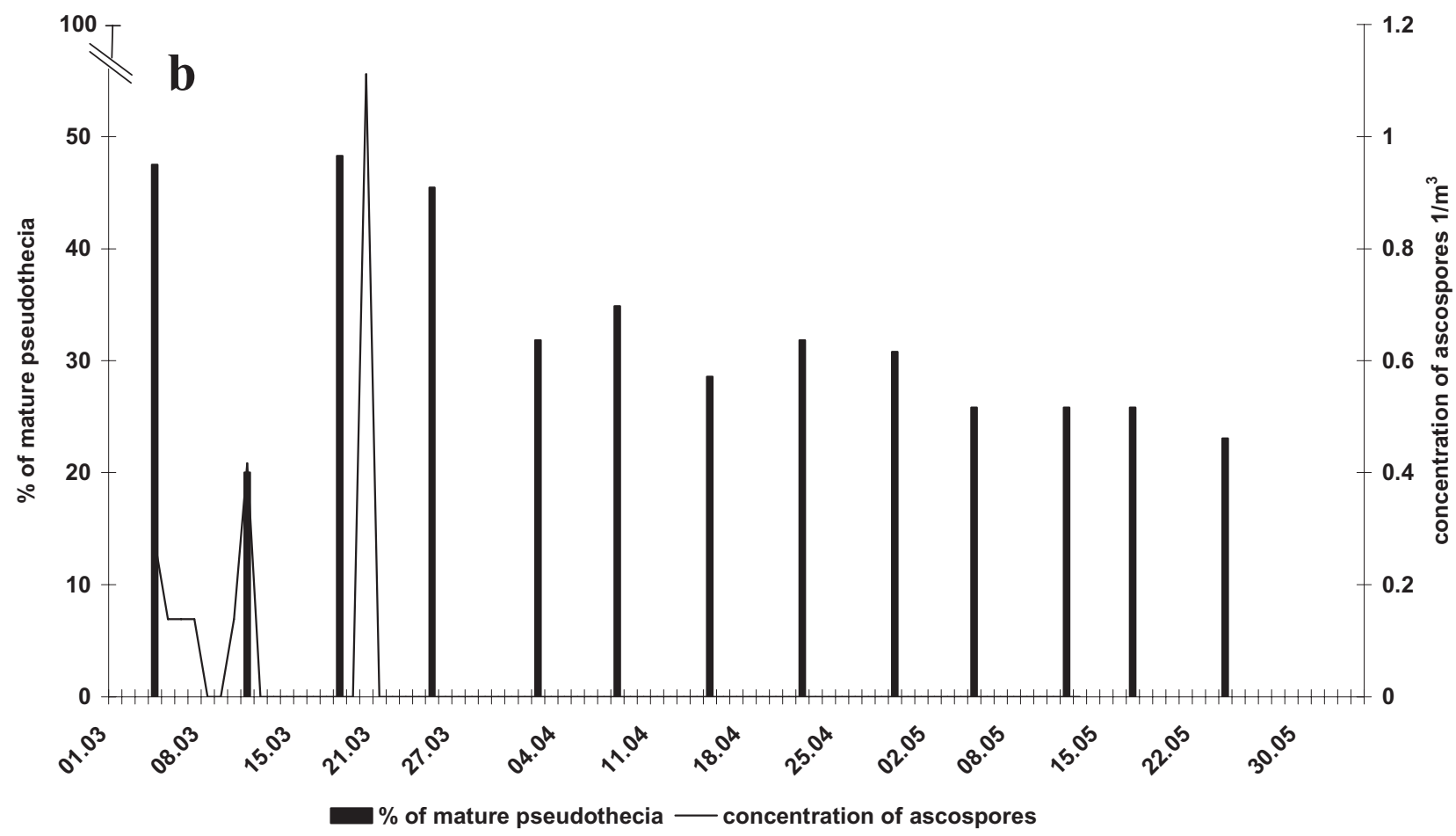

Fig. 5b. The concentration of ascospores in air samples (line) and the percent of mature pseudothecia (bars) of Leptosphaeria maculans and L. biglobosa in Krasne near Rzeszów, Carpathian Foothills in the spring of: a) 2006, b) 2007

The mature pseudothecia of $L$. maculans and L. biglobosa in spring 2006 were observed in the beginning of April and their quantity was estimated at 3.3\% (Fig. 3). The observations performed in spring 2007 showed the presence of developed pseudothecia in the first week of March and their ratio was near to $50 \%$ (Fig. 3).

Ascospore concentration of $L$. maculans and L. biglobosa in air samples

The concentration of airborne ascospores of $L$. maculans and L. biglobosa in Krasne in the autumn of 2005-2007 was very low as compared to the other monitoring sites in Poland (Table 2). The date of the first ascospore appearance as well as the time of the highest concentration of ascospores greatly differed between the seasons.

In 2005 in Krasne the first ascospores were detected on 16 September. The highest concentration of L. maculans and L. biglobosa ascospores in air samples was detected on 20 October; it was 2 spores per cubic meter (Fig. 4a). In this autumn season the ascospores were found on 29 microscope slides, which constituted $31.8 \%$ of samples collected during the studied autumn period (Table 2). In this season the highest amount of spores in the autumn of 2005 was observed in two experiment sites located in the north of Poland: Radostowo (Pomerania) and Rarwino (Maritime region). In this autumn season the mean total number of ascospores for six monitoring sites in Poland was the lowest (108.5 spores per cubic meter), as compared to the other years of this study.

In the autumn 2006 the first ascospores of L. maculans and L. biglobosa in air samples over Krasne were detected on 13 September (Fig. 4b). The highest concentration of ascospores was 1.5 spores per cubic meter; this value was detected on 3 October (Table 2). In this season the earliest detection of ascospores (6 September) concerned air samples from Tarnów (Sudetian Foothills - Upper Silesia). The mean value of the total number of ascospores per $1 \mathrm{~m}^{3}$ for six monitoring sites in Poland was 402.1 spores and the mean number of days with ascospore showers was 48.5 (Table 2), which constituted $53.3 \%$ of the autumn sampling period.

In 2007 the first ascospores in Krasne were observed on 12 September and their highest concentration was found on 20 October (Fig. 4c). Maximum daily mean concentration in this season was 2.5 spores per $1 \mathrm{~m}^{3}$ of air sampled. The spores were found for 16 days. In this season the highest total number of spores was observed in Charbielin (south part of the Opole region). The mean summary number of ascospores for six monitoring sites in Poland was 1572.7 spores per cubic meter (Table 2). The correlation between the 
number of days with $L$. maculans and L. biglobosa ascospores and the summary number of these spores detected in this autumn season was found; the Pearson's correlation coefficient was high $(r=0.678)$.

During spring 2006 the first ascospores of L. maculans and L. biglobosa were found on 20 April (Fig. 5a). The highest concentration of ascospores was noted in the second half of April and it was only a half spore per $1 \mathrm{~m}^{3}$. In the spring 2007 the first ascospores were observed on 1 March (Fig. 5b). The highest concentration of ascospores was noted in the second half of March and it was 1 spore per $1 \mathrm{~m}^{3}$.

The studies performed in two spring seasons showed high differences in pseudothecial maturation rate and ascospore release. The fluctuations in the number of class D pseudothecia and ascospore concentration coincided with the exposition of oilseed rape stubble, inhabited by the fungus, to low temperatures. The data obtained in 2006 showed late pseudothecia maturation, beginning in April with the peak number of class D pseudothecia in mid-April. The ascospore release was observed from mid-April to the beginning of May and the highest ratio of mature pseudothecia was found at the end of April. The situation observed in the spring of 2007 differed both in respect to pseudothecia maturation and ascospore release: fully mature pseudothecia were found over the whole spring season and ranged from $20 \%$ to $48 \%$ of the total pool of fruiting bodies. The ratio of class D pseudothecia was very high from the very beginning of observations, starting at the first days of March, and lasted till the end of May. The ascospores of L. maculans and L. biglobosa also appeared in air samples early in the season and the peak number of these spores was detected in the second half of March 2007. Later on, no ascospores were found till the end of the studied period. These data greatly coincided with the weather conditions. The winter of 2005/2006 was very cold, with temperatures below $0^{\circ} \mathrm{C}$ from the beginning of December 2005 till the end of February 2006. In contrast, the winter season of 2006/2007 was on average $6.1{ }^{\circ} \mathrm{C}$ warmer in the same period of time, which allowed pseudothecia to survive. Moreover, it was possible for the fungus to form new pseudothecia during the winter time. Due to this fact, L. maculans and L. biglobosa ascospores were released as early as the first days of March 2007. In contrast, May 2007 was very warm and dry, which did not allow ascospores to be ejected from pseudothecia, although they were mature enough to release ascospores over the whole spring 2007.

The number of days with ascospores in Krasne varied from 16 (2007) to 29 (2005), whereas in the other sites in Poland the least number of days with an ascospore shower was 21 days (Głębokie, Kujavia 2006) (Table 2). Moreover, the number of ascosporedays could reach as many as 83 days (Charbielin, Opole region 2007), which means that airborne ascospores were present in the atmosphere for most of the days (91.2\%) in the autumn period studied. In Krasne the highest number of days with ascospore showers did not exceed $31.8 \%$. Excluding the data from Krasne, the mean number of days with ascospores present in the air was 54.2 per autumn season $(59.6 \%$ of the sampling autumn period), but only 49 days $(53.8 \%)$ including the results obtained at this location. The concentration of detected spores was negligible; the highest concentration observed was 2.5 spores $/ \mathrm{m}^{3}$ for one day only (20 October 2007), 2 days with 2 spores $/ \mathrm{m}^{3}$ (1 and 19 October 2005), and one day with 1.5 spores $/ \mathrm{m}^{3}$ (4 October 2006). At all other dates, the ascospore concentrations were around 1 spore or even much less, i.e. 1 spore per a few cubic metres. Hence, the summary number of ascospores collected over the season ranged from 9 (2007) to 12 (2005) airborne ascospores only, whereas in the other regions presented in this paper the smallest number of spores was 23 (Charbielin, Opole region 2005) and the highest peaked up to 4347 spores (Charbielin, 2007). The average sum of L. maculans and L. biglobosa ascospores was 831.3 per autumn season, when the samples from Krasne were not considered, but only 694.4 spores when this experiment site was included into the calculation. 


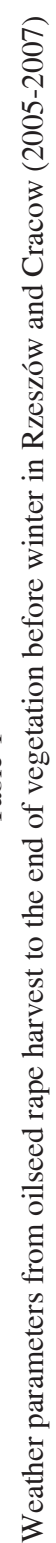

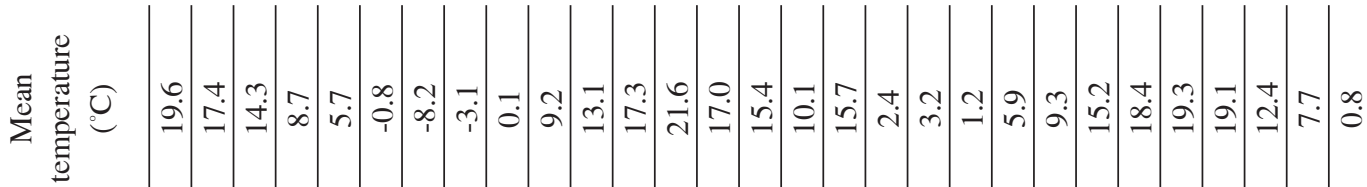
疍

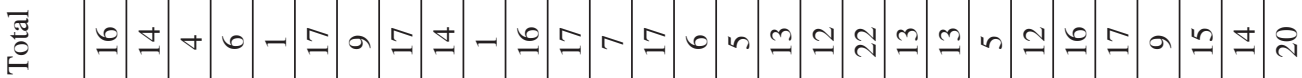

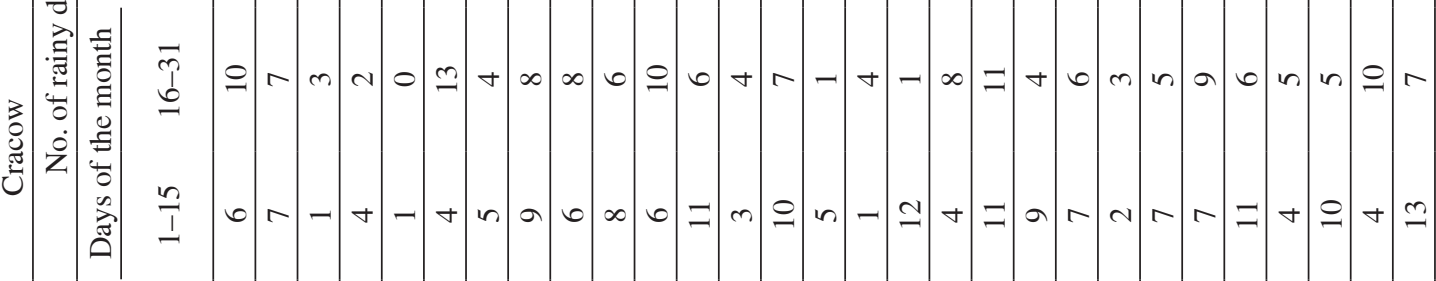

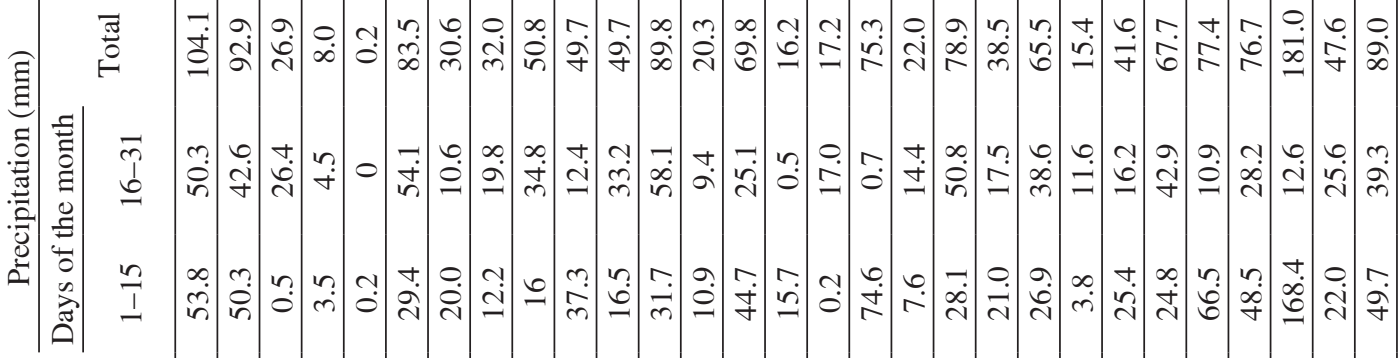

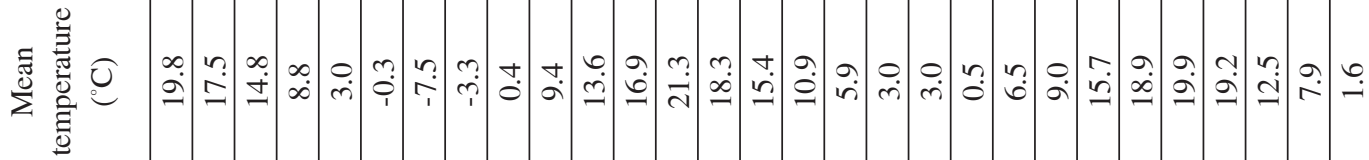

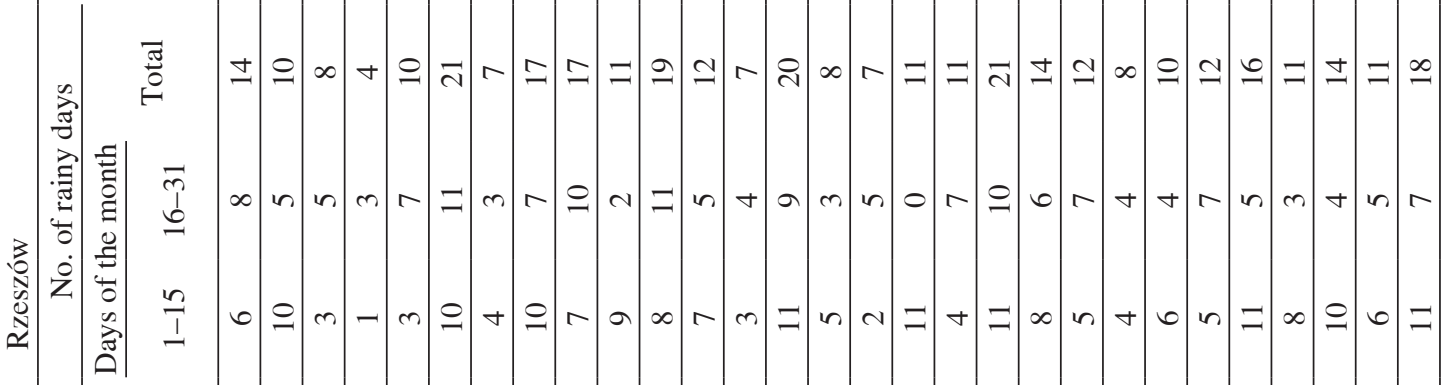

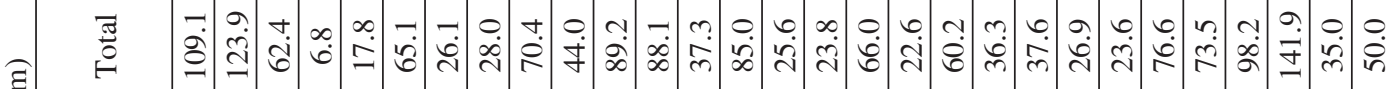

$\Xi$

馬

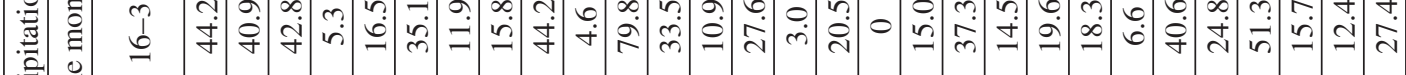

:

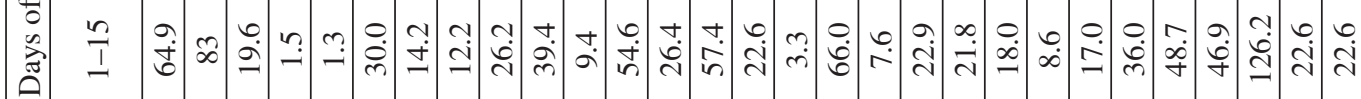

|

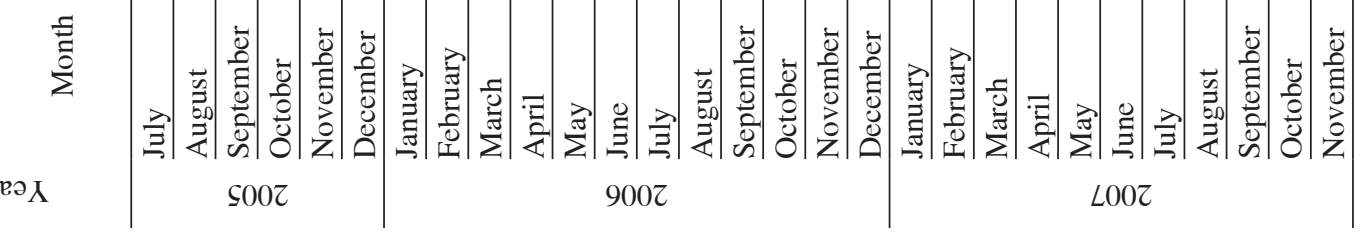


Table 2

The development stages of Leptosphaeria maculans and L. biglobosa at selected locations in Poland in autumn 2005-2007

\begin{tabular}{|c|c|c|c|c|c|c|c|}
\hline \multicolumn{2}{|c|}{$\begin{array}{l}\text { Region and } \\
\text { experiment site }\end{array}$} & Year & $\begin{array}{c}\text { Date of first } \\
\text { ascospore } \\
\text { detection }\end{array}$ & $\begin{array}{c}\text { Date of } \\
\text { highest } \\
\text { ascospore } \\
\text { concentration }\end{array}$ & $\begin{array}{c}\text { Total } \\
\text { concentration } \\
\text { of ascospores } \\
\text { during season }\end{array}$ & $\begin{array}{l}\text { Number of } \\
\text { days with } \\
\text { ascospores }\end{array}$ & $\begin{array}{l}\text { Source of } \\
\text { information }\end{array}$ \\
\hline \multirow{3}{*}{ 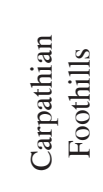 } & \multirow{3}{*}{ 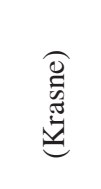 } & 2005 & 16.09 & 2.10 & 12 & 29 & \multirow{3}{*}{$\begin{array}{l}\text { Dawidziuk et al. } \\
2009 \text { (this paper) }\end{array}$} \\
\hline & & 2006 & 13.09 & 3.10 & 10 & 24 & \\
\hline & & 2007 & 12.09 & 20.10 & 9 & 16 & \\
\hline \multirow{3}{*}{ 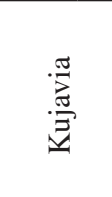 } & \multirow{3}{*}{ 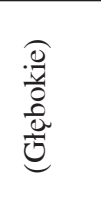 } & 2005 & 28.09 & 4.11 & 36 & 33 & \multirow{3}{*}{$\begin{array}{c}\text { Dawidziuk et al. } \\
2008\end{array}$} \\
\hline & & 2006 & 15.09 & 28.09 & 420 & 21 & \\
\hline & & 2007 & 5.09 & 12.10 & 1976 & 60 & \\
\hline \multirow{3}{*}{ 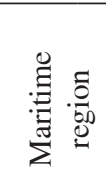 } & \multirow{3}{*}{ 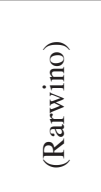 } & 2005 & 22.09 & 5.11 & 220 & 52 & \multirow{3}{*}{$\begin{array}{c}\text { Kaczmarek et al. } \\
2009\end{array}$} \\
\hline & & 2006 & 17.09 & 27.09 & 372 & 57 & \\
\hline & & 2007 & 4.09 & 11.09 & 1568 & 73 & \\
\hline \multirow{3}{*}{$\begin{array}{l}0 \\
.0 \\
0.0 \\
0 \\
0 \\
0 \\
0 \\
0 \\
0\end{array}$} & \multirow{3}{*}{ 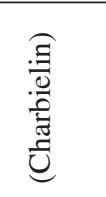 } & 2005 & 12.09 & 29.09 & 23 & 32 & \multirow{3}{*}{$\begin{array}{l}\text { Kaczmarek - } \\
\text { pers. com. }\end{array}$} \\
\hline & & 2006 & 12.09 & 17.11 & 910 & 71 & \\
\hline & & 2007 & 3.09 & 11.10 & 4347 & 83 & \\
\hline \multirow{3}{*}{ 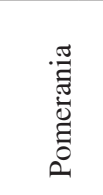 } & \multirow{3}{*}{ 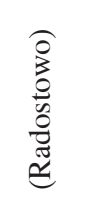 } & 2005 & 9.10 & 5.11 & 323 & 36 & \multirow{3}{*}{$\begin{array}{c}\text { Kaczmarek \& } \\
\text { Jedryczka 2008a }\end{array}$} \\
\hline & & 2006 & 19.09 & 26.11 & 81 & 53 & \\
\hline & & 2007 & 3.09 & 28.09 & 508 & 67 & \\
\hline \multirow{3}{*}{$\begin{array}{l}\frac{\pi}{2} \\
\frac{0}{\sqrt{2}} \\
\dot{\bar{d}} \\
\frac{2}{2}\end{array}$} & \multirow{3}{*}{ 胥 } & 2005 & 12.09 & 23.10 & 37 & 38 & \multirow{3}{*}{$\begin{array}{c}\text { Kaczmarek \& } \\
\text { Jedryczka 2008b }\end{array}$} \\
\hline & & 2006 & 6.09 & 27.09 & 620 & 65 & \\
\hline & & 2007 & 3.09 & 3.10 & 1028 & 72 & \\
\hline \multirow{6}{*}{ 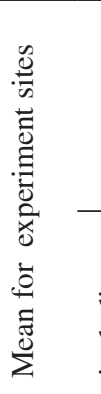 } & \multirow{3}{*}{ 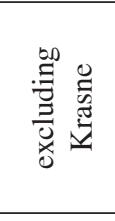 } & 2005 & & & 127,7 & 38,2 & \multirow{6}{*}{$\begin{array}{l}\text { Dawidziuk et al. } \\
2009 \text { (this paper) }\end{array}$} \\
\hline & & 2006 & & the highest & 480,6 & 53,4 & \\
\hline & & 2007 & $\begin{array}{l}\text { the earliest } \\
\text { detection : }\end{array}$ & number of & 1885,5 & 71,0 & \\
\hline & \multirow{3}{*}{ 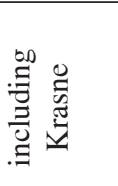 } & 2005 & & during season: & 108.5 & 36.7 & \\
\hline & & 2006 & 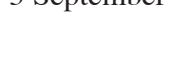 & 4347 & 402.1 & 48.5 & \\
\hline & & 2007 & & & 1572.7 & 61.8 & \\
\hline
\end{tabular}




\section{DISCUSSION}

Knowledge about relationships between life cycles of phytopathogenic fungi, meteorological conditions and crop diseases are crucial elements of decisions concerning the protection of agricultural crops against main pathogens that can greatly decrease plant health, yield and quality.

The release of fungal spores and consequently their concentrations in the air result from complex biological and environmental factors (S tę p a l s k a and W ołek, 2005; K a sprzyk and Wołek, 2006). Links between pseudothecial growth rate of $L$. maculans and L. biglobosa, date of ascospore release and damage caused by stem canker have been demonstrated (To s c a n o-Under w o o d et al. 2003; H u a n g et al. 2005 and 2007). In case of Leptosphaeria, a species attacking oilseed rape, the main source of infection are ascospores produced in pseudothecia developing on infected stubble from a previous cropping season (W e s t et al. 2001). The intensity of pseudothecial maturation of L. maculans and L. biglobosa to a great extent depends on weather conditions - higher humidity increases pseudothecia maturation. The release of ascospores from pseudothecia is also humidity and rainfall dependent ( $\mathrm{H} \mathrm{u}$ a n g et al. 2007; O live ir a et al. 2009). Usually the differences in pseudothecial maturation in the autumn within one climatic region of Poland were small and did not exceed a week (J ę d r y c z k a et al. 2008).

In most cases, the pseudothecial maturation rate was a good indication of an approaching period of ascospore release, followed by plant infection. Exceptionally, in autumn of 2006 the ascospore concentration data superimposed on class D pseudothecia fluctuations were not logically harmonized i.e. generative stage spores were detected in air samples before the fully mature fruiting bodies were found. It is difficult to explain this phenomenon, but it is possible that some 'Leptosphaeria type' ascospores observed under a microscope had a similar shape and size, but belonged to species different from L. maculans or L. biglobosa. Such inconsistency of results could be elucidated with molecular tools such as Real-Time PCR detection of DNA present in air samples with species-specific primers for particular fungi of interest (K a c z m a re k et al. 2009).

The studies performed in Krasne and Śledziejowice showed high differences in the development of subsequent stages of the pathogens' life cycles. The maturation of pseudothecia and subsequent concentration of the ascospores in the autumn coincided with temperature and rainfall following the harvest time and in the spring correlated with temperatures observed over the winter period. Such big differences in Leptosphaeria spp. pseudothecial maturation, depending on weather conditions, were also observed in the United States ( $\mathrm{Xu}$ et al. 1987; Hershman and Perkins, 1995), France (Pérčs et al. 1999), Germany (Thürwä chter et al. 1999), Great Britain (West et al. 1999 and 2004; Huang et al. 2005), Canada (Guo and Fernando, 2005) and Australia (We s t et al. 2001; How le t t 2004). The pseudothecial maturation process is very dynamic and flexible. In the Carpathian Foothills and Cracow region the differences between the date of harvest and first mature pseudothecia were about 8 to 10 weeks, whereas the same process in Australia was taking from 10 to 27 weeks (K h a n g u r a et al. 2007). The length of this period directly influenced the time of ascospore release and subsequent plant infections.

The L. maculans and L. biglobosa ascospore concentrations in the air over Krasne greatly differed between the years, especially in the autumn seasons. The dates of the first ascospore detection were in all years around mid-September and differed at most by 4 days only, but all the other parameters greatly varied between the seasons. There were considerable differences (18 days) between the dates of the highest concentration of ascospores; in autumn 2005 and 2006 this phenomenon took place in the first days of October, whereas in the autumn 2007 it was in the second half of October. The number of days with ascospores differed by 13 days and ranged from 16 to 29 days, which constituted from $17 \%$ to $32 \%$ of the whole period of study. The number of days with ascospores correlated to the total sum of ascospores in a particular season. The highest number of ascospore-days noted in the autumn 2005 coincided with the highest number of ascospores in air samples from this region. In autumn 2006 , the number of days with ascospores and the total number of $L$. maculans and L. biglobosa ascospores were intermediate, whereas the lowest parameters of both characters were found in 2007. Comparable results were obtained at five other sites across Poland (Dawidziuk et al. 2008; Kaczmarek and J ę d r y c z k a , 2008ab; K a c z m a re k et al. 2009).

The concentration of spores in the air depends on weather conditions, but differs between fungal species to a large extent (Stę palska and Wołek, 2005). Ascospores of the genus Leptosphaeria belong to the group of "wet spores" that prefer warmth and humidity (O liveira et al. 2009). Kacz marek and J ę d r y c z k a (2008a) demonstrated that regular rainfall events throughout the whole summer season created very good conditions for pseudothecial maturation and led to abundant release of ascospores of L. maculans and L. biglobosa.

In south-east Poland the differences in ascospore release of these two species also depended on weather, which greatly varied between the three autumn 
seasons studied. The highest total number of ascospores found in the autumn 2007 most probably resulted from the hisghest rainfall, which totalled $313 \mathrm{~mm}$ from the beginning of July to the end of September and 336.2 $\mathrm{mm}$ to mid-October. After harvest in 2005 the amount of rainfall did not reach $300 \mathrm{~mm}$, both by the end of September and also by mid-October. In the autumn 2006, when the smallest total number of ascospores in air samples was noted, as well as the smallest number of rainy days, the summary precipitation was half of the amount observed in 2005 and a few percent less as compared to the autumn 2007. Such a small amount of rain was most probably too little to trigger ascospore release, although it was big enough to allow pseudothecia maturation. It is therefore possible to detect considerable numbers of mature pseudothecia but no ascospores in the air.

The most striking differences between the Carpathian Foothills and the other regions in Poland was a significantly smaller number of days with ascospores as well as the smaller total number of ascospores of $L$. maculans and L. biglobosa. The concentrations of detected spores were negligible. The explanation of this phenomenon is most probably a small initial amount of inoculum in the atmosphere over the Carpathian Foothills, where the cultivation of oilseed rape is expanding but still not very high. Prolonged time of oilseed rape plants' exposition to the ascospores of $L$. $\mathrm{macu}$ lans and L. biglobosa in the other regions of Poland resulted in high plant infection ( $\mathrm{Kac}$ z mare $\mathrm{k}$ and J ę d r y c z k a , 2008ab). The shorter and less intensive appearance of their spores in south-east Poland is the obvious reason of much smaller plant damage.

The results concerning life cycle development of plant pathogenic fungi, including Leptosphaeria spp., are necessary for effective chemical treatments (Thürwächter et al. 1999). The aerobiological data help to point out crucial periods of oilseed rape plant infestation. In Poland, autumn periods were definitely more important for starting the disease process as compared to spring seasons, similarly to the situation in the UK ( $\mathrm{S} \mathrm{u} \mathrm{n}$ et al. 2000). Based on previous experiments of $\mathrm{Ham}$ mond et al. (1985), it is now commonly understood that the source of damaging stem canker symptoms observed before harvest results from leaf spotting initiated by ascospores. This study explained why stem canker of brassicas in south-east Poland is not as frequent and damaging as in the other regions of Poland.

\section{CONCLUSIONS}

1. Pseudothecial maturation rates and ascospore release of L. maculans and L. biglobosa in the autumn depend on mean daily temperature and summary daily rainfall after the harvest of oilseed rape in the previous vegetative season, whereas in the spring they coincide with air temperatures over the winter.

2. The sum of ascospores of L. maculans and L. biglobosa in a particular season correlates to the number of days with ascospores observed in the air over the autumn.

3. The main reason for relatively small infections of oilseed rape plants in south-east Poland is a short exposition of plants to ascospore showers and very small concentration of Leptosphaeria spp. ascospores in the air of this region.

\section{Acknowledgments}

The experiments were done in the framework of the SimMat project funded by DuPont Poland. We want to express our thanks to the L'Arche Community of handicapped persons in Śledziejowice for regular deliveries of infected oilseed rape stubble, with special gratitude to Jolanta Lichman, Ewa Krawczyk, Grzegorz Batko and Barbara Pestka - the Director of the Community.

\section{REFERENCES}

Bartkowiak-Broda I., Muśnicki Cz., Grzebisz W., Praczyk T., 2005. Development of oilseed rape. [In]: I. Bartkowiak-Broda, M. Mrówczyński, Cz. Muśnicki, (eds), Technology of oilseed rape production. Wieś Jutra, Warszawa: 40-51 (in Polish).

Dawidziuk A., Kaczmarek J., Jędryczka M., 2008. Pseudothecia maturation and ascospore release of Leptosphaeria maculans and L. biglobosa in Kujavia region (2005-2007). Rośliny Oleiste - Oilseed Crops, 29 (2): 149-161 (in Polish).

Fit t B. D. L., Brun H., B arbett i M. J. Rimmer S. R., 2006. World-wide importance of phoma stem canker (Leptosphaeria maculans and L. biglobosa) on oilseed rape (Brassica napus). Eur. J. Plant Pathol. 114: 3-15.

Gugel R. K., Petrie G. A., 1992. History, occurrence, impact and control of blackleg of rapeseed. Can. J. Plant Pathol. 14: 36-45.

Gu o X. W., Fern and o W. G. D., 2005. Seasonal and diurnal patterns of spore dispersal by Leptosphaeria maculans from Canada stubble in relation to environmental conditions. Plant Dis. 89: 97-104.

GUS, 2009. Brassica napus and Brassica rapa. Plant production. Departament Rolnictwa i Gospodarki Żywnościowej. Główny Urząd Statystyczny, Warszawa (in Polish).

Ham mond K. E., Lew is B. G., Mus a T. M., 1985. A systemic pathway in the infection of oilseed rape plants by Leptosphaeria maculans. Plant Pathol. 34: 557565.

Hersh m an D. E., Perkin s D. M., 1995. Etiology of canola blackleg in Kentucky and seasonal discharge patterns of 
Leptosphaeria maculans ascospores from infested canola stubble. Plant Dis. 79: 1225-1229.

Hjelmroos M., 1993. Relationship between airborne fungal spore presence and weather variables. Grana, 32: 40-47.

Howlett B. J., 2004. Current knowledge of the interaction between Brassica napus and Leptosphaeria maculans. Can. J. Plant Pathol. 26: 245-252.

Huang Y. J., Fitt B. D. L., Jedryczka M., West J. S., Gladders P., Steed J. M., Li Z. Q., 2005. Patterns of ascospore release in relation to phoma stem canker epidemiology in England (Leptosphaeria maculans) and Poland (Leptosphaeria biglobosa). Eur. J. Plant Pathol. 111: 253-277.

Hu ang Y. J., Liu Z., West J. S., Todd A. D., Hall A. M., Fit t B. D. L., 2007. Effects of temperature and rainfall on date of release of ascospores of Leptosphaeria maculans (phoma stem canker) from winter oilseed rape (Brassica napus) debris in the UK. Ann. Appl. Biol. 151: 99-111.

Huang Y. J., Toscano-Underwood C., Fitt B. D. L., $\mathrm{Hu}$ X. J., Hall A. M., 2003. Effects of temperature on ascospore germination and penetration of oilseed rape (Brassica napus) leaves by A-group or B-group Leptosphaeria maculans (phoma stem canker). Plant Pathol. 52: 245-255.

Jędryczka M., 2007. Epidemiology and damage caused by stem canker of oilseed rape in Poland. Phytopathol. Pol. 45: 73-75.

Jędryczka M., Kaczmarek J., Dawidziuk A., Brachaczek A., 2008. System for Forecasting Disease Epidemics - Aerobiological methods in Polish agriculture. Aspects Appl. Biol. 89: 65-70.

Jędryczka M., Lewartowska E., Frencel I., 1994. Properties of Phoma lingam (Tode ex Fr.) Desm. isolates from Poland. I. Pathogenicity characterisation. Phytopathol. Pol. 7 (19): 71-79.

Ję dry czk a M., Mat ysi a k R., Grah a m K., 2004. LeptoNet and SPEC - new projects supporting the control of stem canker of oilseed rape in Poland. IOBC Bull. 27 (10): 125-130.

Kaczmarek J., Mączyńska A., Kasprzyk I., Le wandowski A., Jędryczka M., 2006. Patterns of Leptosphaeria maculans/ L. biglobosa ascospore release in the season 2004/2005 in Poland. IOBC Bull. 29 (7): $259-265$.

K a cz marek J., Ję dryczka M., 2008a. Development of the perfect stage of Leptosphaeria maculans and L. biglobosa under variable weather conditions of Pomerania in 2004-2008. Phytopathol. Pol. 50: 19-31.

K a c z marek J., Jęd r yc zka M., 2008b. The risk of infection by phoma stem canker on oilseed rape in Lower Silesia in 2004-2007. Rośliny Oleiste - Oilseed Crops, 29 (1): $37-51$ (in Polish).

K a cz marek J., Jędryczka M., Fitt B. D. L., Lucas J. A., Latunde-Dada A.O., 2009. Analyses of air samples for ascospores of Leptosphaeria maculans and L. biglo- bosa with light microscopic and molecular techniques. J. Appl. Gen. 50 (4): 411-419.

K a rolew s k i Z., Kosiada T., Hylak-Nowosad B. and Nowacka K., 2002. Changes in population structure of Leptosphaeria maculans in Poland. Phytopathol. Pol. 25: 27-34.

Kasprzyk I., Wołek M., 2006. Airborne fungal spores in urban and rural environments in Poland. Aerobiologia, 22: $169-176$.

Khangura R., Speijers J., Barbetti M. J., Salam M. U., Diggle J., 2007. Epidemiology of blackleg (Leptosphaeria maculans) of canola (Brassica napus) in relation to maturation of pseudothecia and discharge of ascospores in Western Australia. Phytopathology, 97:1011-1021.

Khangura R. K., Barbetti M., 2001. Prevalence of blackleg (Leptosphaeria maculans) on canola (Brassica napus) in Western Australia. Aust. J. Exp. Agric. 41: 71-80.

L a c e y M. E., We st J. S., 2006. The Air Spora - A manual for catching and identifying airborne biological particles. Springer, Dordrecht.

Oliveira M., Ribeiro H., Delgado J.L., Abreu I., 2009. The effects of meteorological factors on airborne fungal spore concentration in two areas differing in urbanisation level. Int. J. Biometeorol. 53: 61-73.

Péres A., Poisson B., Le Sourne V., Maisonneuve C., 1999. Leptosphaeria maculans: effect of temperature, rainfall and humidity on the formation of pseudothecia. Proceedings of the $10^{\text {th }}$ International Rapeseed Congress, Canberra, Australia; www.regional.org.au/ au/gcirc/3/106.

Petri e G. A., 1995. Patterns of ascospore discharge by Leptosphaeria maculans (blackleg) from 9- to 13-month-old naturally infected rapeseed/canola stubble from 1977 to 1993 in Saskatchewan. Can. Plant Dis. Surv. 75: 35-43.

Salisbury P. A., B allinger D. J., Wratten N., Plummer K. M., Howlett B. J., 1995. Blackleg disease on oilseed Brassica in Australia: a review. Aust. J. Exp. Agric. 35: 665-672.

S a la m M. U., Khangura R. K., Diggle A. J., B arbett i M. J., 2003. Blackleg Sporacle: A model for predicting onset of pseudothecia maturity and seasonal ascospore showers in relation to blackleg of canola. Phytopathology, 93: 1073-1081.

Shoemaker R. A., Brun H., 2001. The teleomorph of the weakly aggressive segregate of Leptosphaeria maculans. Can. J. Bot. 79: 412-419.

Stępalska D., Wołek J., 2005. Variation in fungal spore concentrations of selected taxa associated to weather conditions in Cracow, Poland, in 1997. Aerobiologia, 21: 43-52.

Sun P., Fitt B. D. L., Gladders P., Welham S. J., 2000. Relationships between phoma leaf spot and development of stem canker (Leptosphaeria maculans) on winter oilseed rape (Brassica napus) in southern England. Ann. Appl. Biol. 137: 113-125.

Thürwächter F., Garbe V., Hoppe H. H., 1999. Ascospore discharge, leaf infestation and variations in 
pathogenicity as criteria of predict impact of Leptosphaeria maculans on oilseed rape. J. Phytopathol. 147: 215-222.

Toscano-Underwood C., Huang Y. J., Fitt B. D. L., Hall A. M., 2003. Effects of temperature on maturation of pseudothecia of Leptosphaeria maculans and L. biglobosa on oilseed rape stem debris. Plant Pathol. 52: 726-736.

We st J. S., Biddulph J. E., Fitt B. D. L., Gladders P., 1999. Epidemiology of Leptosphaeria maculans in relation to forecasting stem canker severity on winter oilseed rape in the UK. Ann. Appl. Biol., 135: 535-546.

West J. S., Jędryczka M., Penaud A., Fitt B. D. L., 2004. Comparing fungal diseases on oilseed rape in England, France and Poland. IOBC Bull., 27 (10): 39-44.

We st J. S., K h a rb a nd a P. D., B a rbett i M. J., Fit t B. D. L., 2001. Epidemiology and management of Leptosphaeria maculans (phoma stem canker) on oilseed rape in Australia, Canada and Europe. Plant Pathol. 50: 10-27.

X u X. H., Hill C. B., Willi a m s P. H., 1987. Environmental conditions for the production of pseudothecia of Leptosphaeria maculans. Acta Mycol. Sinica, 6: 236-241.

\section{Dojrzewanie pseudotecjów i uwalnianie askospor grzybów Leptosphaeria maculans i L. biglobosa w południowo-wschodniej Polsce}

\section{Streszczenie}

Sucha zgnilizna kapustnych jest groźną chorobą rzepaku w Australii, Kanadzie i Europie, w tym także w Polsce. Jej przyczyną są dwa gatunki grzybów: Leptosphaeria maculans i L. biglobosa należące do klasy Dothideomycetes. Oba gatunki różnią się pod względem chorobotwórczości, lecz tworzą owocniki i zarod- niki o identycznych kształtach i wymiarach, zarówno w przypadku formy generatywnej jak też konidialnej. Reizolacje patogenów z porażonych roślin rzepaku wskazują, że oba gatunki bardzo często występują w kompleksie.

Głównym celem pracy było określenie szybkości dojrzewania pseudotecjów oraz oznaczenie stężenia zarodników workowych grzybów L. maculans i L. biglobosa $\mathrm{w}$ próbach powietrza zebranych w południowo-wschodniej części Polski (Podkarpacie i okolice Krakowa). Badania prowadzono przez trzy kolejne lata (2005-2007), corocznie przez 6 miesięcy najważniejszych dla rozprzestrzeniania się patogena z wiatrem i zakażania roślin, w tym 3 miesiące w okresie wiosennym (marzec - maj) oraz 3 miesiące jesienią (wrzesień - listopad). Stadium dojrzewania pseudotecjów oznaczano pod mikroskopem, na podstawie budowy owocników oraz znajdujących się w nich zarodników. Stężenie zarodników workowych określano przy zastosowaniu 7-dniowej pułapki typu Hirsta.

Wykazano, że w obrębie jednego sezonu różnice w szybkości dojrzewania owocników w południowo-wschodniej Polsce nie przekraczają dwóch tygodni. Terminy pierwszej detekcji i najwyższego stężenia askospor były ściśle powiązane $\mathrm{z}$ warunkami pogodowymi. Całkowita liczba zarodników uwolnionych w sezonie jesiennym wahała się od 9 do 12 askospor $/ \mathrm{m}^{3}$, co stanowiło od 70 do 90 razy mniej niż średnia z pięciu innych miejsc monitorowania, położonych w różnych regionach Polski. Krótka ekspozycja roślin na inokulum i niewielkie stężenie askospor w powietrzu były najbardziej prawdopodobną przyczyną małych strat plonu rzepaku spowodowanych suchą zgnilizną kapustnych w południowo-wschodniej części Polski. 